\title{
Political Uncertainty and Stock Returns: Evidence from the Brazilian Political Crisis
}

\author{
David Hillier, Tiago Loncan ${ }^{1}$ \\ Department of Accounting $\& 3$ Finance \\ Strathclyde Business School \\ University of Strathclyde \\ Glasgow, United Kingdom
}

\begin{abstract}
This paper examines the effect of political uncertainty on stock returns, exploiting an exogenous shock to political stability in Brazil. In May, 2017, a conversation between Brazil's President and a businessman was bugged by Brazilian Police and leaked to the media. This led to sudden political instability and a collapse in the equity market. We decompose the cross-sectional variation of abnormal returns around this event and investigate whether corporate political connections and exposure to foreign capital were factors in the price falls. Our results show that firms connected with the Brazilian state-owned development bank, BNDES, and firms cross-listed via ADRs (American Depositary Receipts) were most affected by this shock. The evidence suggests that political connections and foreign capital exposure are factors in channeling political risk to asset prices, increasing the cost of equity capital during periods of political instability.

Keywords: Political uncertainty, Stock returns, Corporate political connections, Foreign capitals
\end{abstract}

\section{Introduction}

In this paper, we examine firm-level evidence on the effect of political uncertainty on asset prices. Political uncertainty can shake stock markets, with adverse effects spilling-over to both financial (e.g. asset prices), and economic (e.g. investment cycles) domains. Previous research has identified the negative impact of political uncertainty on stock returns at an aggregate level (Pastor \& Veronesi, 2013). With a growing interest on the link between finance and politics, a focussed study at the firm-level on the effects of political uncertainty on asset prices is important.

Extant literature provides guidance on two cross-sectional stock characteristics that may in-

\footnotetext{
${ }^{1}$ Corresponding author. Email: tiago.rodrigues-loncan@strath.ac.uk
} 
fluence the sensitivity of asset prices to political risk: political connections and foreign capital exposure. While political uncertainty naturally affects the value of political connections to connected businesses (Liu et al. , 2017), political instability is more often associated with capital flight (Alesina \& Tabellini, 1989). We argue that stocks of firms with political connections and of firms more exposed to foreign investors are more affected by political uncertainty.

The impact of political uncertainty in emerging markets has received attention (e.g. Chinese focus of Liu et al. (2017)). Our paper adds to the literature by investigating the direct impact of the Brazilian political crisis that began in 2012. The Brazilian equity market is an ideal laboratory for a study of this nature for a number of reasons. First, the country has been facing a period of strong political instability since 2012, rooted in two major corruption scandals: Mensalão (2012) and the Carwash probe involving Petrobras (2014). In both scandals senior government officials were implicated for corruption and sparked instability in the Brazilian political outlook.

Second, government subsidies have increased since the 2008 financial crisis, mainly through funding granted by the Brazilian state-owned bank BNDES. However, it has been argued that subsidies seem to be politically motivated (Carvalho, 2014), with no clear economic basis for the granting criteria. Resources have been channeled to firms via both equity ownership and loans. As noted by Leahy (2015), around 60\% of BNDES lending goes to large conglomerates known as National Champions, commanded by business tycoons with close relations with government officials. Moreover, the bank usually holds significant minority equity stakes in these firms as well. $^{2}$ It is fair to suggest that through this policy, BNDES became a shareholder with strong political capital, capable of influencing corporate decisions. Third, being a major emerging market destination for foreign institutional investors, the Brazilian stock market is highly exposed to foreign capital flows.

In this context, we exploit a unique and unexpected political uncertainty event. Between 17th and 18th of May, 2017, a compromising conversation between Brazil's President and an influential business tycoon was bugged and leaked by the Brazilian Justice Department, in which the President allegedly condoned bribing a key witness in the Carwash probe, likely because such testimony could add aggravating evidence about government involvement in the corruption scheme. As the leak became public, the stock market posted heavy losses of around $9 \%$ (the worst trading day since the Great Financial Crisis of 2008). Not only did equity prices collapse, but sovereign credit spreads soared by $15 \%$, and the Brazilian currency suffered a devaluation against the U.S dollar, losing $7 \%$ of its value.

This unexpected exogenous event allows us to decompose the cross-sectional variation of stock returns and investigate if two important firm-level characteristics, namely political connections,

\footnotetext{
${ }^{2}$ See the story at: https://www.ft.com/content/c510368e-968e-11e4-922f-00144feabdc0
} 
as proxied by firms' relationships with the Brazilian State-Owned bank BNDES, and exposure to foreign capital, as proxied by cross-listing in the U.S exchange via American Depositary Receipts, work as catalysts in channeling the effect of political uncertainty to stock returns.

Our results provide evidence that the effect of political uncertainty on stock returns is stronger for politically connected firms. The stocks of firms in which BNDES holds equity ownership stakes posted weaker cumulative abnormal returns when compared to firms not invested by the state-owned bank. While this evidence suggests that the political influence acquired by BNDES via equity ownership triggers devaluations when the market faces political instability, our results offer no evidence that debt loaned by BNDES had any effect on stock prices during this episode. Regarding exposure to foreign capital, our findings provide some evidence that firms with ADRs trading in the U.S market also suffered larger devaluations. Our results are robust to the inclusion of control variables, industry fixed effects, alternative measurement of political connections (BNDES board and fiscal committee membership), and alternative event windows.

The paper contributes to three major streams of research. The first is the literature examining the effects of political uncertainty on stock returns. On a conceptual basis, Pastor \& Veronesi (2013) provide a solid theoretical framework to examine the implications of political uncertainty to stock prices. On an empirical and theoretically-consistent basis, two recent papers have shown that political uncertainty is priced in the stock market (Liu et al. (2017) for China and Kelly et al. (2016) with international evidence). Our paper contributes to this literature, by providing evidence, from a major emerging market, Brazil, that political connections and exposure to foreign capital are important firm-level characteristics channeling political instability to asset prices.

The second contribution relates to the literature on corporate political connections. While previous research supports the view that political connections are associated with higher firm valuation (Cooper et al. , 2010; Faccio, 2006; Fisman, 2001) and lower cost of capital (Boubakri et al. , 2012b), we show evidence of a particular and highly relevant circumstance, e.g, political uncertainty, under which political linkages can have a negative impact on firm valuation and cost of capital. The third is the literature on political risk and foreign investments. In line with theoretical and empirical literature (Alesina \& Tabellini, 1989; Lensink et al. , 2000; Papaioannou, 2009), our results indicate that political risk may trigger capital flight, as firms with ADRs listed in the U.S market might be more exposed to political uncertainty.

Our findings have implications for the practice of finance and policy making. First, we provide valuable guidance to fund managers on where not to invest in times of political uncertainty: politically linked and foreign-exposed firms. Second, we show that relying too much on foreign capital, and especially, on corporate political connections, can have downsides in times of political turmoil. Finally, we highlight the potential costs of state involvement in the corporate sector.

The rest of the paper is organised as follows. In Section 2, we discuss the theoretical framework 
and propose testable hypotheses. Section 3 describes the research design and data. In Section 4 we present our results, and in Section 5 we conduct sensitivity checks. Section 6 concludes.

\section{Theory and hypothesis development}

Our theoretical framework is built on three distinct literature groups. The first is the literature on systemic (macroeconomic) determinants of asset prices, which provides insights on the role of unexpected shocks to political stability in affecting stock returns. The second is the literature on rent-seeking and political connections. The third is the literature on international capital flows and financial integration. By integrating these three literatures, we discuss the heterogeneous effects of political uncertainty on stock returns caused by political connections and foreign capital exposure.

Following Chen et al. (1986), uncertainty related to systemic forces, mostly unexpected shocks to prevailing political and economic conditions, can affect asset prices through two channels: expected cash flows and discount rates. Whilst the effect of cash flows captures changes in sales and profits produced by shifts in consumer demand, the effect of discount rates reflects innovations in perceived risks, as negative (positive) shocks to economic or political variables may increase (decrease) investors' required compensation for risk. As noted by Pastor \& Veronesi (2013), political uncertainty can have ambiguous effects on market prices. If government responds appropriately when intervening in times of trouble, this can be interpreted as a protective put option on asset prices, leading to positive effects on market prices. On the other hand, political uncertainty can produce a negative effect on market prices, because political uncertainty is a source of non-diversified risk, depressing asset prices by raising the discount rate.

Political uncertainty also affects the behaviour of sovereign credit risk, which is a chief factor affecting interest rates and ultimately discount rates. Political uncertainty is shown to increase the probability of borrowing countries to default on or reschedule their public debts (Brewer \& Rivoli, 1990; Balkan, 1992), driving upwards spreads and default risks on domestic sovereign debt (Cuadra \& Sapriza, 2008). Moreover, political uncertainty makes stock prices more volatile and correlated, which increases risk premiums and expected returns (Pastor \& Veronesi, 2013; Veronesi, 1999).

Political uncertainty can also spread to firms' cash flows, by undermining economic growth (Darby et al. , 2004), mostly through negative effects on productivity and human capital accumulation (Aisen \& Veiga, 2013) and by reducing corporate investment (Julio \& Yook, 2012). Deterioration in economic conditions, in turn, can make consumers more cautious about spending, with a shift of income from consumption to precautionary savings. This can slow down firms' sales and ultimately decrease cash flows. In summary, changes in perceived risks channelled through the discount factor and adjustments in cash flows are the main rationales linking political uncertainty with stock returns, and the resulting effect can be positive or negative, depending on how market participants and consumers interpret signals. 
Although our discussion suggests that the effect of political uncertainty on stock prices can be ambiguous, its impact will be heterogeneous across firms. For instance, Johnson et al. (1999) provide evidence of heterogeneous effects of presidential political cycles in the U.S stock market, with small-cap firms posting higher returns during Democrat administrations compared to Republican offices, though large caps perform similarly under both parties. A review of the literature suggests two important firm-level characteristics that may potentially affect the relationship between political uncertainty and stock returns: corporate political connections and foreign capital exposure.

Corporate political connections are valuable assets that can be built in a variety of ways. While firms can gain the favour of politicians via donations to political campaigns (Cooper et al. , 2010), and corporate lobbying efforts (Yu \& Yu, 2012), governments establish links with firms by granting preferential access to credit via state-owned banks (Lazzarini et al. , 2015; Carvalho, 2014), or by government membership in corporate boards (Faccio, 2006).

Exchanges of favours benefit both industrialists and politicians. On the corporate side, theories of rent-seeking behaviour assert that politically-connected industrialists profit from government connections to extract benefits, particularly related to lower funding costs (Ades \& Di Tella, 1997), and facilitated access to credit (Boubakri et al. , 2012b). On the politicians' side, they may use lending by government banks to influence the behaviour of firms, further benefiting from patronage and electoral support (Carvalho, 2014), using governments' control over countries' financial resources to bargain for political support and obtain private benefits (Lazzarini et al. , 2015).

In an efficient market, the benefits from political connections should be priced as a political asset and reflected in stock prices. In fact, politically connected firms enjoy a lower cost of equity capital, with political ties viewed as factors reducing firms' overall riskiness (Boubakri et al. , 2012a) and increasing corporate valuations and stock returns (Cooper et al. , 2010; Faccio, 2006; Fisman, 2001). In light of this, it might be the case that political connections may shield connected firms' cost of capital through such lower riskiness during periods of political turmoil, while non-connected firms may, instead, take the full hit and be relatively more affected by uncertainty.

Hypothesis I.a: The effect of political uncertainty on stock returns is weaker for politically connected firms.

On the other hand, political uncertainty may cast doubts on whether existing government ties will continue, for a turnover in office may jeopardise friendly relations between government officials and firms. Recent evidence from the Bo scandal in China suggests that stock prices of politically connected or sensitive firms are more negatively affected by political uncertainty, because growing uncertainty about power transition may increase the likelihood that political connections lose their 
value (Liu et al. , 2017). Taken together, these arguments point to the possibility of two conflicting effects of political uncertainty on stock returns of politically connected vis-a-vis non-connected firms, hence a hypothesis predicting an opposite effect is also proposed:

Hypothesis I.b: The effect of political uncertainty on stock returns is stronger for politically connected firms.

Insights from the financial integration literature suggest that foreign investment exposure may also play a role in channelling the effects of political uncertainty to asset prices. The flow of equity capital to emerging economies render these markets more financially integrated with global capital markets (Hillier \& Loncan, 2017). While the process of integration is shown to bring about benefits, in particular increases in stock prices (Chari \& Henry, 2004), a crucial determinant of the level of financial integration is institutional quality (Carrieri et al. , 2013). As an important element of countries' institutional setting, political risk is shown to undermine financial integration, making emerging markets pervasively segmented from global markets (Bekaert et al. , 2011). Just like financial integration increases stock prices, segmentation, its reciprocal, is associated to higher expected returns (de Jong \& de Roon, 2005) and decreases in stock prices.

The closely related international foreign capital flows literature yields similar predictions on how foreign investment may interact with political uncertainty and affect asset prices. Likewise in this literature, institutional quality is an important determinant of international financial flows (Papaioannou, 2009). In particular, political risk increases the threat of opportunistic expropriation faced by foreign firms and investors (Henisz, 2000), with political uncertainty causing negative effects on foreign investments (Busse \& Hefeker, 2007). Consistent with this, increased riskiness in the political outlook leads to substantial foreign capital flight away from politically exposed countries (Lensink et al. , 2000; Alesina \& Tabellini, 1989). Political risk is also shown to affect exchange rates, with the reaction of the foreign exchange market being more dramatic for unfavourable political events (Cosset \& de la Rianderie, 1985). Moreover, firms employing substantial foreign financing can be more exposed to adverse changes in currency and capital flows (Bailey \& Chung, 1995).

In the context of this discussion, political uncertainty may trigger foreign capital flight, disturb financial integration and contribute to a setback towards segmentation away from global equity markets. Foreign investors, often sophisticated funds with global reach, can sell their positions in the country affected by political uncertainty more easily than local investors, reallocating their capital towards other emerging markets with more stable politics. These factors suggest that the effect of political uncertainty may be more pronounced for firms with higher exposure to foreign investors, because the trading pressure from overseas investors might be stronger as these firms 
are more exposed to global markets. We thus hypothesise that firms with higher foreign exposure are more affected by political uncertainty.

Hypothesis II: The effect of political uncertainty on stock returns is stronger for firms with higher exposure to foreign capital.

\section{Research design and data}

\subsection{Defining and identifying an exogenous political uncertainty event}

A challenge is to disentangle political uncertainty from macroeconomic and policy uncertainty because of their close relationship. Following Kelly et al. (2016), we isolate political uncertainty by exploiting its variation around major political events.

Our natural experiment is the Carwash corruption probe (Operação Lava Jato) in Brazil. Carwash is an investigation by the Brazilian Federal Police and Judiciary which uncovered an unprecedented large scale corruption scheme in the state-owned oil company Petrobras and involving high profile industrialists and government officials. While any criminal government investigation is strongly political, the secret nature of police investigations implies that news is released at unexpected times.

Amongst all the searches, interrogations and arrests, one particular event provides a unique opportunity to isolate and study a truly exogenous shock to political stability: the bugging by the Brazilian Justice Department of a conversation between Brazil's President and a business tycoon, followed by the leaking of this conversation to the media. In this recording, the President allegedly condoned bribes to silence a key witness in the Carwash probe, mostly because an eventual testimony from this witness would deepen the political crisis. We refer to this event hereafter as the Political uncertainty shock.

The Political uncertainty shock triggered a surge in government instability with the widespread expectation that the government would not survive such a scandal. Immediately after the recording was leaked, the stock market collapsed, with equities falling sharply, closing at $-9 \%$, the largest daily decline since the 2008 financial crisis. This episode was widely covered in the local and international media. Bloomberg, for instance, issued a headline: Brazil plunges back into Political Crisis as Markets Brace (Adghirni et al. , 2017). ${ }^{3}$

The literature provides some insight that characterises this event as a source of exogenous variation in political uncertainty. Besides affecting stock prices, political uncertainty is also shown to affect sovereign credit default risks (Cuadra \& Sapriza, 2008) and local currencies (Cosset \&

\footnotetext{
${ }^{3} \mathrm{~A}$ link for the full story can be found at: https://www.bloomberg.com/news/articles/2017-05-18/ brazil-newspaper-alleges-president-involved-in-cover-up-scheme
} 
de la Rianderie, 1985). In Figure 1, we show the reaction of stock prices (returns of the Brazilian IBOVESPA index), default risk (returns of the EMBI+ index, which captures the spread on Brazilian sovereign bonds) and the exchange rate between the Brazilian Real and the U.S Dollar (returns of the Real/Dollar rate).

Date 0 (zero) marks the first trading day absorbing the new information content from the Political uncertainty shock (18/05/2017). We plot the evolution of stock returns, default risks and currency returns 5 days before and after the political shock. While stock prices fell by $9 \%$, the spread on Brazilian government bonds soared by $15 \%$, and the Brazilian Real depreciated by $7 \%$ against the U.S dollar. Since the major expected impacts of a surge in political uncertainty materialised during the Political uncertainty shock, this event fits the profile of an unexpected shock to political stability.

Figure 1: Political Shock, Stock Returns, Exchange Rate and Default Risk

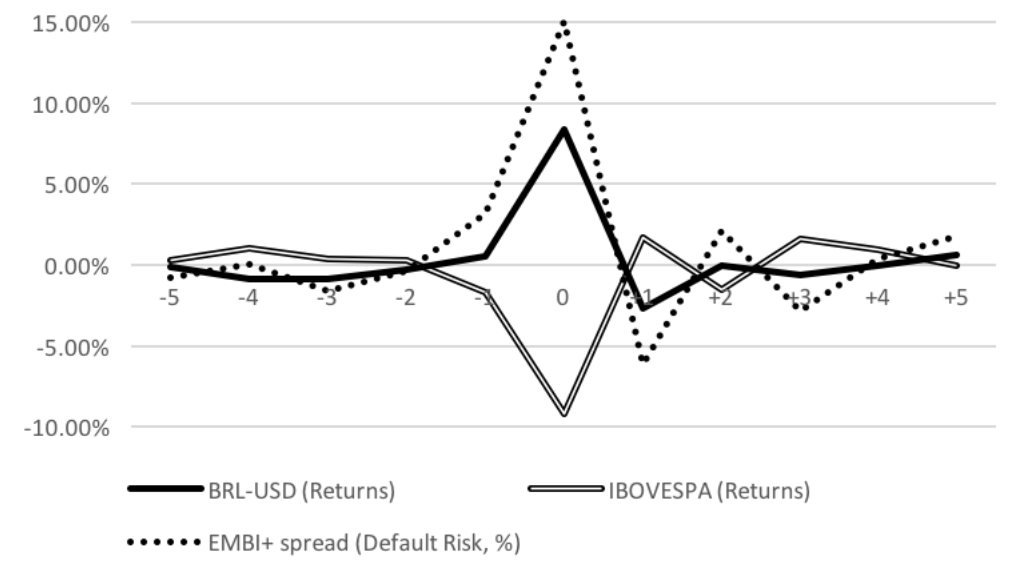

To further strengthen the claim of a political shock, we look at the variation in quantitative measures of political stability around our political uncertainty event. A political stability scale widely employed in finance research is provided by the International Country Risk Guide (ICRG).

As Figure 2 shows, the Political Stability Index by ICRG takes a hit in the Month of May, 2017, precisely the period in which our Political uncertainty shock took place. The graphical evidence presented in Figures 1 and 2 provide further evidence to support for characterising the scandal as a Political uncertainty shock.

\subsection{Definition of variables and empirical models}

The empirical study investigates the effect of political uncertainty on stock returns, using cumulative abnormal stock returns (CAR) as the dependent variable. Abnormal returns are calculated as the difference between the total return and the value-weighted market return. For a political 
Figure 2: Government Stability Index - ICRG

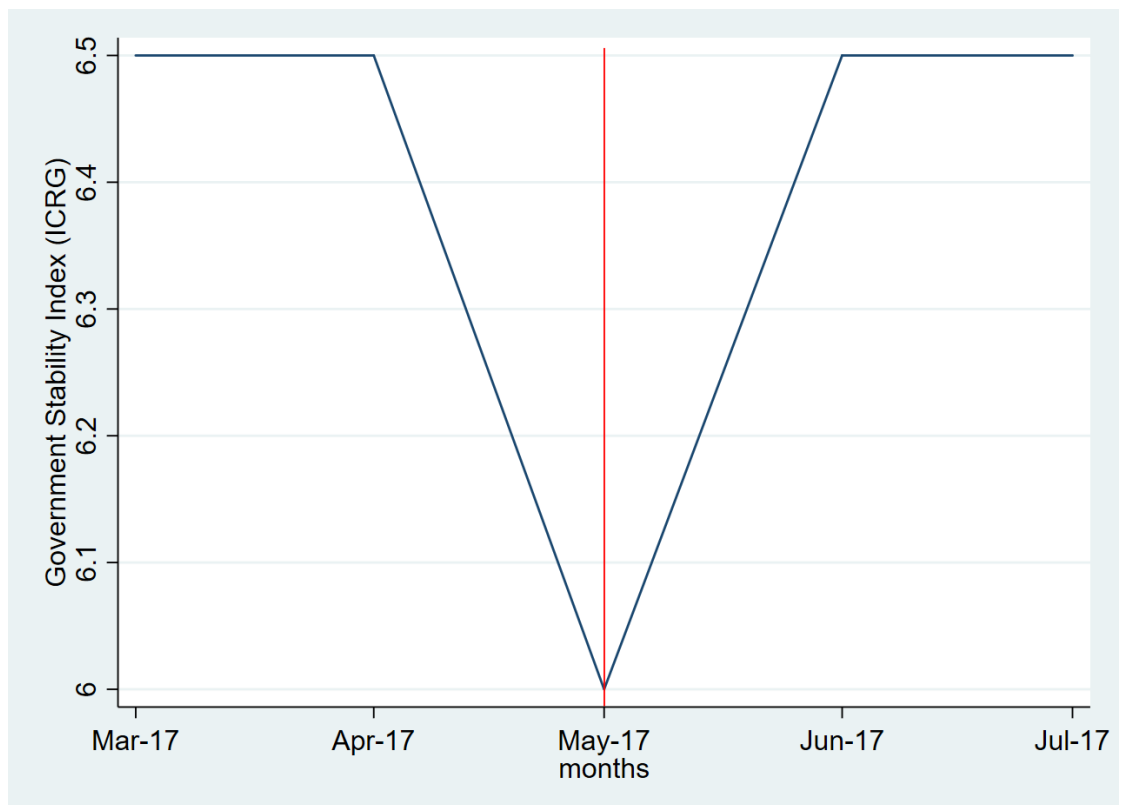

event occurring on day t, we specify an event window running between $\mathrm{t}-5$ and $\mathrm{t}+5$ (with robustness tests for a t-10, t+10 window). Abnormal stock returns (AR) and Cumulative abnormal stock returns $(\mathrm{CAR})$ are given by:

$$
\begin{aligned}
& A R_{i t}=R_{i t}-R_{m t} \\
& C A R_{i}=\sum_{t-5}^{t+5} A R_{i t}
\end{aligned}
$$

We employ two main explanatory variables in the analysis: political connections and foreign capital exposure. We distinguish politically connected or sensitive firms $\left(\right.$ PolCon $\left._{i}\right)$, building on the state-owned development banks and political connections literature (Lazzarini et al. , 2015; Claessens et al. , 2008). As the main measure of the political influence of BNDES over firms' decisions, we use the ownership stake held by BNDES calculated as a share of equity capital, PolconEquity . We further test alternative measures of political connections in sensitivity checks.

We also use a proxy variable to capture the involvement of BNDES officials on a firm's corporate governance. This is labeled PolconBoard , $_{i}$ and is defined as a dummy variable equal to 1 if BNDES officials were indicated to the board or fiscal committee, and equal to zero otherwise. ${ }^{4}$ We also

\footnotetext{
${ }^{4}$ There is no data available on the number of officials indicated, reason why we employ a dummy.
} 
consider the role of debt supplied by BNDES as a source of political influence. PolconDebt Pis $_{i}$ calculated as the sum of BNDES loans divided by total debt, and PolconEquity + Debt $_{i}$ is the sum of BNDES equity and debt investment scaled by total firm capital (total equity plus total debt).

Following the literature on international cross listing and asset pricing, exposure to foreign capital and foreign investors is proxied by ADR issuance (Doidge et al. , 2004; Fernandes, 2009). We code a dummy variable $\left(A D R_{i}\right)$, taking the value of 1 for Brazilian firms listed on the U.S market via American Depositary Receipts, and zero otherwise. Firms listed in an important foreign exchange such as the U.S are more exposed to foreign investors and are more likely to receive equity capital from abroad.

A standard event study methodology is employed in order to assess the effect of political uncertainty on stock returns (Liu et al. , 2017; MacKinlay, 1997; Ball \& Brown, 1968). We estimate a cross-sectional regression, modelling cumulative abnormal returns around the Political uncertainty shock as a function of political connections $\left(\right.$ PolCon $\left._{i}\right)$ and foreign capital exposure $\left(A D R_{i}\right)$. A vector of control variables, which could affect stock returns and potentially be correlated with our main explanatory variables is further added to the model. Equations 3 and 4 are estimated:

$$
\begin{gathered}
C A R_{i}=\alpha+\alpha_{j}+\delta \text { PolCon }_{i}+\beta \text { Controls }_{i}+\epsilon \\
C A R_{i}=\alpha+\alpha_{j}+\gamma A D R_{i}+\beta \text { Controls }_{i}+\epsilon
\end{gathered}
$$

The hypotheses discussed in Section 2 are explicitly tested by the models. A statistically significant and positive delta coefficient provides support for Hypothesis I.a, whilst if delta is statistically significant and negative, then Hypothesis I.b is supported. Similarly, if gamma is statistically significant and negative, Hypothesis II is corroborated.

Controls for firm size (log of total sales) and stock liquidity (monthly traded volume divided by shares outstanding) are included because firms invested by BNDES and foreign investors tend to be large and liquid. We control for growth opportunities (Tobin's Q) because foreign investors tilt their portfolios towards high growth firms. Capital structure (debt/assets) is an important control to separate the effects of BNDES loans from other loans supplied by private banks and creditors.

We include a dummy variable to control for nationality, and is equal to 1 if the controlling shareholder is an overseas investor, and zero otherwise. We control for dividends because foreign investors may prefer dividends-paying firms. Dividends is defined as a dummy, equal to 1 if firms pay dividends (dividend yield greater than zero), and equal to zero otherwise. Lastly, because some industries may be more prone to both political connections and foreign capital exposure, we include industry (3 digit SIC code) fixed effects $\left(\alpha_{j}\right)$. To net-out exchange rate exposure, all variables are expressed in U.S dollars. The explanatory variables correspond to the year of 2016 , 
the fiscal year preceding the political shock of May, 2017.

\subsection{Data}

Stock market, financial and ownership data is from Bureau Van Dijk (Osiris). Firm-level data on BNDES equity investments is manually collected from the bank's website. ${ }^{5}$ The list of Brazilian stocks with ADRs trading on U.S stock exchanges is obtained from Valor Econômico business and economics newspaper. ${ }^{6}$

The initial sample included 382 actively listed firms in the Brazilian stock market. We imposed an initial filter by excluding stocks from financial institutions (banks). Second, we dropped stocks that did not trade during the $[-10,+10]$ Political uncertainty shock event window. Because many equities in the Brazilian market are illiquid and do not trade on a daily basis, this filter removes a number of outliers from the sample. The final dataset includes 159 firms. Table 1 presents descriptive statistics of the sample and Table 4 in the Appendix shows industry statistics.

Table 1: Summary Statistics

\begin{tabular}{lcccccc}
\hline \hline Variables & Mean & St. Dev & $\mathrm{p} 25$ & $\mathrm{p} 50$ & $\mathrm{p} 75$ & $\mathrm{p} 95$ \\
\hline \hline Returns (t= political shock) & -0.104 & 0.063 & -0.148 & -0.101 & -0.0644 & -0.003 \\
Cum. returns (t-5, 0, t+5) & -0.048 & 0.250 & -0.125 & -0.069 & -0.013 & 0.132 \\
Cum. abnormal returns (t-5, 0, t+5) & 0.052 & 0.250 & -0.023 & 0.032 & 0.088 & 0.234 \\
Cum. abnormal returns (t-10, 0, t+10) & 0.064 & 0.257 & -0.0218 & 0.042 & 0.115 & 0.293 \\
Polcon equity share & 0.021 & 0.059 & 0 & 0 & 0 & 0.187 \\
ADR (0/1) & 0.125 & 0.332 & 0 & 0 & 0 & 1 \\
Polcon board (0/1) & 0.100 & 0.301 & 0 & 0 & 0 & 1 \\
Polcon debt share & 0.108 & 0.288 & 0 & 0 & 0.0779 & 0.566 \\
Polcon equity + debt/ capital & 0.0613 & 0.135 & 0 & 0 & 0.059 & 0.362 \\
Polcon equity (USD MM) & 149.436 & 1093.820 & 0 & 0 & 0 & 213.278 \\
Polcon debt (USD MM) & 195.5066 & 668.0805 & 0 & 0 & 78.4 & 1054.700 \\
Polcon equity+debt (USD MM) & 344.943 & 1467.208 & 0 & 0 & 139.479 & 1443.895 \\
Sales (USD MM) & 2983.962 & 8637.394 & 197.033 & 629.600 & 2255.719 & 12740.220 \\
Equity (USD MM) & 2088.405 & 7289.171 & 140.952 & 471.298 & 1475.732 & 7167.208 \\
Debt (USD MM) & 3786.703 & 14691.850 & 249.583 & 777.464 & 2395.365 & 11284.060 \\
Liquidity & 143.1156 & 245.4981 & 33.999 & 87.704 & 150.759 & 483.338 \\
Tobin's Q & 0.676 & 1.015 & 0.148 & 0.347 & 0.7600 & 2.303 \\
Debt/Assets & 0.668 & 0.496 & 0.443 & 0.572 & 0.773 & 1.399 \\
Foreign control (0/1) & 0.188 & 0.392 & 0 & 0 & 0 & 1 \\
Dividends (0/1) & 0.113 & 0.317 & 0 & 0 & 0 & 1 \\
Firms & 159 & & & & & \\
\hline \hline
\end{tabular}

Out of the total number of firms in the final sample, 38 companies received equity investments from BNDES (24\% of total sample) and 60 companies received debt (37\% of total sample). A total of 16 companies (10\% of total sample) have BNDES officials indicated to their board or fiscal committees. There are 20 firms in the final sample which have ADRs trading in the U.S market ( $12 \%$ of total sample). The mean for BNDES equity ownership is $2 \%$, although for those firms on

\footnotetext{
${ }^{5}$ Source: https://www.bndes.gov.br/wps/portal/site/home/transparencia/centraldedownloads

${ }^{6}$ Source: http://www.valor.com.br/valor-data/tabela/5792/adr-brasil
} 
the top of the distribution (95 percentile), this value was as high as $19 \%$ on average. Average debt share supplied by BNDES was $10.8 \%$.

Average normal stock returns in the Political uncertainty shock trading day was $-10 \%$. Firms experiencing the strongest losses (25\% of the distribution) had $-15 \%$ stock returns, on average. The median returns are similar to the mean returns (-10\%). The cumulative normal returns on a $-5,0,+5$ event window was $-4 \%$. Cumulative abnormal returns (after netting out the market cumulative return, which was $-10 \%$ in the $-5,0,+5$ event window) is $+5 \%$. Hence, after netting out market losses, the average cumulative abnormal return turns positive, suggesting the average firm in the sample experienced no abnormal losses due to the political shock. In other words, the devaluations were systemic, akin to a political shock.

\section{Results}

Regression results are reported in Table 2. Cumulative abnormal returns $(-5,0,+5)$ around the Political uncertainty shock is the dependent variable. In the model shown in (1), Political Connections is the explanatory variable, calculated as the share of firms' equity capital held by BNDES. Results show that companies linked with BNDES via equity ownership experienced statistically significantly stronger negative returns during the Political uncertainty shock. This finding provides support for Hypothesis I.b, suggesting that the effect of political uncertainty on stock returns is stronger for politically connected firms.

In the model output reported in (2), Exposure to Foreign Capital, as proxied by ADR crosslisting, is the main explanatory variable. Our findings show that firms with ADRs trading in the U.S exchange experienced a statistically stronger devaluation around the political shock (significant at 0.10 level, though). This finding indicates that firms more exposed to foreign equity investments suffer more from political uncertainty, providing modest statistical support for Hypothesis II.

With respect to the control variables, larger firms seem to have been relatively insulated from the political uncertainty shock, as the effect of firm size on cumulative abnormal returns is statistically significant and positive. On the other hand, firms with more liquid stocks, with better growth opportunities and higher degrees of leverage took a stronger negative hit from the political shock. Foreign control and dividends are not statistically significant in the models.

Regarding model fit, the $R^{2}$ and Adjusted $R^{2}$ statistics (0.78 and 0.48 , respectively) suggest that a substantial fraction of the cross-sectional variation in cumulative abnormal returns has been accounted for. The evidence of good model fit, together with the statistical significance of important control variables, vouch for a reliable estimation of the effects of political connections and exposure to foreign capitals on stock returns during the Political uncertainty shock.

Our findings are in line with the evidence reported by Liu et al. (2017) for the Chinese market during an unexpected political uncertainty event, as we also find that political uncertainty exerts 
a stronger negative effect on politically linked firms. This may be because political uncertainty increases the risk that political ties will lose their value as the risk of turnover in government increases. The results we report on stronger effects for foreign-exposed firms provide some evidence aligned with the notion of capital flight following escalation of political instability (Alesina \& Tabellini, 1989; Lensink et al. , 2000), since foreign investors may have dumped Brazilian stocks to get rid of political risk.

\section{Robustness checks}

\subsection{Alternative proxies for political influence}

The results presented in columns (3), (4) and (5) of Table 2 are for models with alternative

proxies for political influence. In model (3), we employ a dummy variable for the presence of BNDES officials on corporate boards and fiscal committees as a proxy for political influence. In columns (4) and (5), we examine the role of BNDES debt as a source of political influence.

Our results suggest a statistically significant and negative effect of political uncertainty on the returns of those firms whose management is more influenced by state-appointed board members, further corroborating Hypothesis I.b. As per the results reported in (4) and (5), we find no statistically significant effect of BNDES debt provided on abnormal returns.

\subsection{Alternative event window and other tests}

In this sub-section, a series of sensitivity tests are carried out using an alternative event window. This helps to mitigate issues related to event study uncertainty and overlapping events. We replace the standard $(-5,0,+5)$ window with a $(-10,0,+10)$ window.

As reported in Column (1) of Table 3, the effect of PolconEquity $y_{i}$ on stock returns during the political shock remains statistically significant and negative, despite enlarging the event window. On the other hand, results shown in column (2) suggest that the effect of ADR cross-listing is not robust to a longer event window. All other coefficients qualitatively remain the same.

A number of other tests were carried out to ensure our results are robust to statistical methods (not shown for brevity). First, we estimate the models imposing heteroskedastic standard errors. Second, we estimate the model with Polcon and ADR included in the same equation. While the effect of political connections remained significant and negative, ADR cross-listing is not significant. Third, we exclude from the analysis two important firms controlled by the federal government (Petrobras and Eletrobras). Being both state-controlled and equity-invested by BNDES, this double exposure to politics can distort the effect of political connections. Despite dropping these firms, our results are qualitatively similar.

Fourth, we tested for joint effects of equity ownership and board participation, by interacting PolconEquity $_{i}$ with PolconBoard P $_{i}$. We did not find any statistically significant results suggesting 
Table 2: The effect of political uncertainty on stock returns

This table reports regression results. Cumulative abnormal returns around the Political uncertainty shock, CAR, (t-5, $0, t+5)$ is the dependent variable. In model 1 , Political influence via equity, PolconEquity $y_{i}$, is the independent variable, calculated as the share of firms' equity capital held by BNDES (the Brazilian state-owned development bank). In model 2, the explanatory variable is exposure to foreign capital $\left(A D R_{i}\right)$, calculated as a dummy equal to 1 for the firms with ADRs (American Depositary Receipts) trading in the U.S stock exchange, and zero otherwise. In model 3, PolconBoard $i$, is employed as a proxy for political influence, calculated as a dummy equal to 1 for firms in which BNDES officials have been indicated for the board or fiscal committee, and equal to zero otherwise. In model 4 , the explanatory variable is political influence via debt, PolconDebt $i_{i}$, calculated as the value of debt supplied by BNDES as a share of total debt. In model 5 , the explanatory variable is equity plus debt supplied by BNDES a share of total firms' capital (total debt plus total equity). All models include control variables: firm size (log of total sales), liquidity (traded volume as a share of outstanding shares), Tobin's Q, leverage (debt/assets), foreign control (equal to 1 if foreign controlled, zero otherwise), dividends (equal to 1 for firms paying dividends, and zero otherwise), plus industry fixed effects (3-digit SIC code). ${ }^{* * *}$ Significant at 0.01 level; ** Significant at 0.05 level; * Significant at 0.1 level.

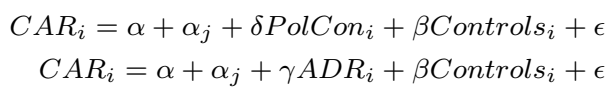

\begin{tabular}{|c|c|c|c|c|c|}
\hline $\bar{y} y=C A R_{i}(5 \mathrm{~d})$ & 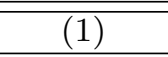 & $\overline{\overline{(2)}}$ & 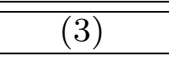 & $\overline{(4)}$ & 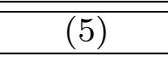 \\
\hline Polcon equity & $\begin{array}{c}-0.051^{* *} \\
(0.025)\end{array}$ & & & & \\
\hline $\operatorname{ADR}(0 / 1)$ & & $\begin{array}{c}-0.148^{*} \\
(0.088)\end{array}$ & & & \\
\hline Polcon board (0/1) & & & $\begin{array}{c}-0.163^{* *} \\
(0.071)\end{array}$ & & \\
\hline Polcon debt & & & & $\begin{array}{c}0.003 \\
(0.162)\end{array}$ & \\
\hline Polcon equity + debt & & & & & $\begin{array}{l}-0.136 \\
(0.293)\end{array}$ \\
\hline Size & $\begin{array}{c}0.063^{* * *} \\
(0.016)\end{array}$ & $\begin{array}{c}0.066^{* * *} \\
(0.017)\end{array}$ & $\begin{array}{c}0.059 * * * \\
(0.015)\end{array}$ & $\begin{array}{c}0.053^{* * *} \\
(0.015)\end{array}$ & $\begin{array}{c}0.055^{* * *} \\
(0.015)\end{array}$ \\
\hline Liquidity & $\begin{array}{c}-0.001^{* * *} \\
(0.000)\end{array}$ & $\begin{array}{c}-0.001^{* * *} \\
(0.000)\end{array}$ & $\begin{array}{c}-0.001^{* * *} \\
(0.000)\end{array}$ & $\begin{array}{c}-0.001^{* * *} \\
(0.000)\end{array}$ & $\begin{array}{c}-0.001^{* * *} \\
(0.000)\end{array}$ \\
\hline Tobin's Q & $\begin{array}{c}-0.114^{* * *} \\
(0.024)\end{array}$ & $\begin{array}{c}-0.105^{* * *} \\
(0.024)\end{array}$ & $\begin{array}{c}-0.113^{* * *} \\
(0.024)\end{array}$ & $\begin{array}{c}-0.107^{* * *} \\
(0.025)\end{array}$ & $\begin{array}{c}-0.106^{* * *} \\
(0.025)\end{array}$ \\
\hline Leverage & $\begin{array}{c}-0.179 * * * \\
(0.056)\end{array}$ & $\begin{array}{c}-0.177^{* * *} \\
(0.057)\end{array}$ & $\begin{array}{c}-0.182^{* * *} \\
(0.056)\end{array}$ & $\begin{array}{c}-0.194^{* * *} \\
(0.058)\end{array}$ & $\begin{array}{c}-0.192 * * * \\
(0.058)\end{array}$ \\
\hline Foreign control $(0 / 1)$ & $\begin{array}{c}0.013 \\
(0.064)\end{array}$ & $\begin{array}{c}0.018 \\
(0.064)\end{array}$ & $\begin{array}{c}0.009 \\
(0.063)\end{array}$ & $\begin{array}{c}0.031 \\
(0.066)\end{array}$ & $\begin{array}{c}0.027 \\
(0.066)\end{array}$ \\
\hline Dividends (0/1) & $\begin{array}{c}0.116 \\
(0.073)\end{array}$ & $\begin{array}{c}0.100 \\
(0.074)\end{array}$ & $\begin{array}{l}0.130^{*} \\
(0.074)\end{array}$ & $\begin{array}{c}0.098 \\
(0.075)\end{array}$ & $\begin{array}{c}0.099 \\
(0.075)\end{array}$ \\
\hline Constant & $\begin{array}{c}-0.999^{* * *} \\
(0.258)\end{array}$ & $\begin{array}{c}-1.010^{* * *} \\
(0.265)\end{array}$ & $\begin{array}{c}-0.937^{* * * *} \\
(0.249)\end{array}$ & $\begin{array}{c}-0.869^{* * *} \\
(0.257)\end{array}$ & $\begin{array}{c}-0.878^{* * *} \\
(0.258)\end{array}$ \\
\hline Industry fixed effects & Yes & Yes & Yes & Yes & Yes \\
\hline$R^{2}$ & 0.788 & 0.784 & 0.791 & 0.774 & 0.775 \\
\hline Adjusted $R^{2}$ & 0.484 & 0.474 & 0.491 & 0.451 & 0.453 \\
\hline Number of Obs. & 159 & 159 & 159 & 159 & 159 \\
\hline F-statistic & $2.595^{* * *}$ & $2.532^{* * *}$ & $2.645^{* * *}$ & $2.397 * * *$ & $2.408^{* * *}$ \\
\hline
\end{tabular}


Table 3: The effect of political uncertainty on stock returns - Robustness checks

This table reports robustness checks. Cumulative abnormal daily returns around the Political uncertainty shock, CAR $(\mathrm{t}-10,0, \mathrm{t}+10)$ is the dependent variable. In model 1 , Political influence via equity, PolconEquity ${ }_{i}$, is the independent variable, calculated as the share of firms' equity capital held by BNDES (the Brazilian state-owned development bank). In model 2 , the explanatory variable is exposure to foreign capital $\left(A D R_{i}\right)$, calculated as a dummy equal to 1 for the firms with ADRs (American Depositary Receipts) trading in the U.S stock exchange, and zero otherwise. In model 3 , PolconBoard $i$, is employed as a proxy for political influence, calculated as a dummy equal to 1 for firms in which BNDES officials have been indicated for the board or fiscal committee, and equal to zero otherwise. In model 4 , the explanatory variable is political influence via debt, PolconDebt $t_{i}$, calculated as the value of debt supplied by BNDES as a share of total debt. In model 5, the explanatory variable is equity plus debt supplied by BNDES a share of total firms' capital (total debt plus total equity). All models include control variables: firm size (log of total sales), liquidity (traded volume as a share of outstanding shares), Tobin's Q, leverage (debt/assets), foreign control (equal to 1 if foreign controlled, zero otherwise), dividends (equal to 1 for firms paying dividends, and zero otherwise), plus industry fixed effects (3-digit SIC code). ${ }^{* * *}$ Significant at 0.01 level; ** Significant at 0.05 level; $*$ Significant at 0.1 level.

$$
\begin{array}{r}
C A R_{i}=\alpha+\alpha_{j}+\text { SPolCon }_{i}+\beta \text { Controls }_{i}+\epsilon \\
C A R_{i}=\alpha+\alpha_{j}+\gamma A D R_{i}+\beta \text { Controls }_{i}+\epsilon
\end{array}
$$

\begin{tabular}{|c|c|c|c|c|c|}
\hline$y=C A R_{i}(10 \mathrm{~d})$ & $(1)$ & $(2)$ & $(3)$ & $(4)$ & $(5)$ \\
\hline Polcon equity & $\begin{array}{c}-0.050^{* *} \\
(0.025)\end{array}$ & & & & \\
\hline $\operatorname{ADR}(0 / 1)$ & & $\begin{array}{l}-0.124 \\
(0.088)\end{array}$ & & & \\
\hline Polcon board (0/1) & & & $\begin{array}{c}-0.158^{* *} \\
(0.071)\end{array}$ & & \\
\hline Polcon debt & & & & $\begin{array}{c}0.021 \\
(0.161)\end{array}$ & \\
\hline Polcon equity + debt & & & & & $\begin{array}{c}-0.091 \\
(0.292)\end{array}$ \\
\hline Size & $\begin{array}{c}0.060^{* * *} \\
(0.016)\end{array}$ & $\begin{array}{c}0.061^{* * *} \\
(0.017)\end{array}$ & $\begin{array}{c}0.056^{* * *} \\
(0.015)\end{array}$ & $\begin{array}{c}0.051^{* * *} \\
(0.015)\end{array}$ & $\begin{array}{c}0.051^{* * *} \\
(0.015)\end{array}$ \\
\hline Liquidity & $\begin{array}{c}-0.001^{* * *} \\
(0.000)\end{array}$ & $\begin{array}{c}-0.001^{* * *} \\
(0.000)\end{array}$ & $\begin{array}{c}-0.001^{* * *} \\
(0.000)\end{array}$ & $\begin{array}{c}-0.001^{* * *} \\
(0.000)\end{array}$ & $\begin{array}{c}-0.001^{* * *} \\
(0.000)\end{array}$ \\
\hline Tobin's Q & $\begin{array}{c}-0.118^{* * *} \\
(0.024)\end{array}$ & $\begin{array}{c}-0.109^{* * * *} \\
(0.024)\end{array}$ & $\begin{array}{c}-0.116^{* * *} \\
(0.024)\end{array}$ & $\begin{array}{c}-0.111^{* * *} \\
(0.025)\end{array}$ & $\begin{array}{c}-0.110^{* * *} \\
(0.025)\end{array}$ \\
\hline Leverage & $\begin{array}{c}-0.205^{* * *} \\
(0.056)\end{array}$ & $\begin{array}{c}-0.206^{* * *} \\
(0.058)\end{array}$ & $\begin{array}{c}-0.208^{* * *} \\
(0.056)\end{array}$ & $\begin{array}{c}-0.220^{* * *} \\
(0.058)\end{array}$ & $\begin{array}{c}-0.219^{* * *} \\
(0.058)\end{array}$ \\
\hline Foreign control $(0 / 1)$ & $\begin{array}{c}0.039 \\
(0.064)\end{array}$ & $\begin{array}{c}0.046 \\
(0.064)\end{array}$ & $\begin{array}{c}0.036 \\
(0.063)\end{array}$ & $\begin{array}{c}0.058 \\
(0.065)\end{array}$ & $\begin{array}{c}0.054 \\
(0.066)\end{array}$ \\
\hline Dividends $(0 / 1)$ & $\begin{array}{c}0.105 \\
(0.073)\end{array}$ & $\begin{array}{c}0.089 \\
(0.074)\end{array}$ & $\begin{array}{c}0.118 \\
(0.074)\end{array}$ & $\begin{array}{c}0.087 \\
(0.075)\end{array}$ & $\begin{array}{c}0.088 \\
(0.075)\end{array}$ \\
\hline Constant & $\begin{array}{c}-0.986^{* * *} \\
(0.257)\end{array}$ & $\begin{array}{c}-0.976^{* * *} \\
(0.266)\end{array}$ & $\begin{array}{c}-0.924^{* * * *} \\
(0.249)\end{array}$ & $\begin{array}{c}-0.857^{* * *} \\
(0.257)\end{array}$ & $\begin{array}{c}-0.864^{* * *} \\
(0.257)\end{array}$ \\
\hline Industry fixed effects & Yes & Yes & Yes & Yes & Yes \\
\hline$R^{2}$ & 0.800 & 0.794 & 0.803 & 0.788 & 0.788 \\
\hline Adjusted $R^{2}$ & 0.513 & 0.499 & 0.520 & 0.484 & 0.484 \\
\hline Number of Obs. & 159 & 159 & 159 & 159 & 159 \\
\hline F-statistic & $2.796^{* * *}$ & $2.693^{* * *}$ & $2.840^{* * *}$ & $2.593^{* * *}$ & $2.597 * * *$ \\
\hline
\end{tabular}


moderation or mediation relationships between these two variables. Lastly, due to a modestly higher allocation of BNDES finance into the Electric sector (8 firms with average 7\% BNDES equity ownership, which is 3.5 times the sample average of $2 \%$ ), we test for an interaction of PolconEquity $i_{i}$ with firms from this industry. The results were not significant.

\subsection{A descriptive analysis of volatility around the Political uncertainty shock}

Our findings have provided evidence that returns of politically connected and foreign exposed firms react more negatively to a political uncertainty shock. Another channel possibly affecting these firms is volatility. If investors consider politically connected and foreign exposed firms to be more risky under political uncertainty, trading pressure may make them more volatile.

We calculate the standard deviation of returns 5 days before and after the Political uncertainty shock (excluding the shock itself), for firms politically connected via equity ownership, for ADR cross-listed firms and for the whole market. Next, we compare the behaviour of volatility through graphical inspection, as shown in Figure 3:

Figure 3: Volatility around the political shock

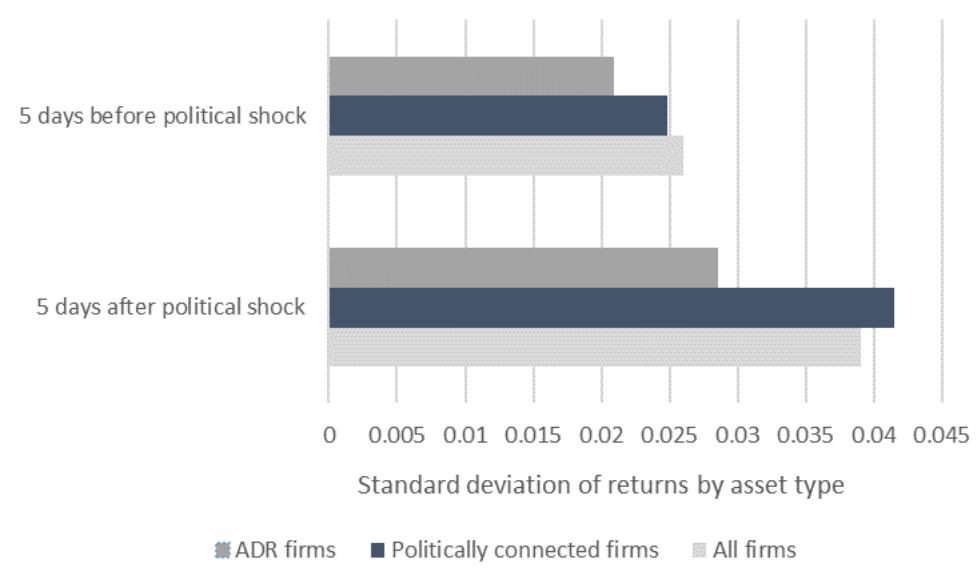

On the upper part of Figure 3, the standard deviation of returns 5 days before the political shock is shown. We can see that before the shock, politically connected and ADR firms experienced lower volatility levels when compared to the whole market. As shown in the lower part of Figure 3 , the standard deviation of returns 5 days after the shock increases for all three groups.

However, the volatility of politically connected firms now surpasses average market volatility, suggesting that returns of politically linked firms became more volatile following the political uncertainty event. This simple graphical volatility analysis further corroborates the findings that politically linked firms suffer more from political instability, via both reductions in prices and increases in volatility. 


\section{Conclusions}

With the increased interest in the link between finance and politics, the role of political uncertainty on the determination of asset prices has received growing attention. This paper adds to the debate by studying how firms' idiosyncratic characteristics affect the uncertainty-returns nexus. The paper exploits an exogenous shock to political stability in Brazil, analysing the stock market reaction to the bugging and leakage of a controversial conversation between Brazil's president and a business tycoon. This event triggered a surge in political instability, priced into the stock market as the Brazilian index lost $9 \%$ of its value in one single trading day, and further reflected in soaring sovereign credit spreads and currency depreciation.

Two important stock characteristics are analysed: we ask if stock returns of politically-connected and foreign-exposed firms are more affected by political instability. Political connections are proxied by corporate relationships with the Brazilian state-owned development bank BNDES, and foreign capital exposure is captured by ADRs (American Depositary Receipts) in the U.S stock market.

By decomposing the cross-sectional variation of returns around this major political uncertainty event, the results from the paper show that corporate political connections are associated with stronger negative returns during this political uncertainty shock. Regarding firms' exposure to foreign investment flows, results also provide some evidence that those firms with ADRs trading in the U.S were more strongly affected by the shock. These findings shed more light on the effects of political uncertainty on asset prices, suggesting that political connections and reliance upon foreign equity capital are two factors catalysing the negative effects of political turmoil into the cross-section of returns and adversely affecting the cost of equity capital.

\section{Acknowledgements}

The authors are grateful for comments and discussions from participants at the International Accounting and Finance Doctoral Symposium (IAFDS) annual meeting, held in Warsaw School of Economics in June, 2017. We are particularly indebted to Helen Bollaert, George Tanewski and the editors, Robert Faff, Marvin Wee and Robert Bradbury for comments and suggestions which helped to improve earlier versions of the paper. All errors are our own

\section{References}

Ades, Alberto, \& Di Tella, Rafael. 1997. National Champions and Corruption: Some Unpleasant Interventionist Arithmetic. Economic Journal, 107(443), 1023-1042.

Adghirni, Samy, Lima, Mario Sergio, \& Gamarski, Rachel. 2017. Brazil Plunges Back Into Political Crisis as Markets Brace. Bloomberg. 
Aisen, Ari, \& Veiga, Francisco Jose. 2013. How does political instability affect economic growth? European Journal of Political Economy, 29(C), 151-167.

Alesina, Alberto, \& Tabellini, Guido. 1989. External debt, capital flight and political risk. Journal of International Economics, 27(3-4), 199-220.

Bailey, Warren, \& Chung, Y. Peter. 1995. Exchange Rate Fluctuations, Political Risk, and Stock Returns: Some Evidence from an Emerging Market. Journal of Financial and Quantitative Analysis, 30(04), 541-561.

Balkan, Erol M. 1992. Political instability, country risk and probability of default. Applied Economics, 24(9), 999-1008.

BAll, R, \& Brown, P. 1968. Empirical Evaluation Of Accounting Income Numbers. Journal of Accounting Research, 6(2), 159-178.

Bekaert, Geert, Harvey, Campbell R., Lundblad, Christian T., \& Siegel, Stephan. 2011. What Segments Equity Markets? Review of Financial Studies, 24(12), 3841-3890.

Boubakri, Narjess, Guedhami, Omrane, Mishra, Dev, \& Saffar, Walid. 2012a. Political connections and the cost of equity capital. Journal of Corporate Finance, 18(3), 541-559.

Boubakri, Narjess, Cosset, Jean-Claude, \& Saffar, Walid. 2012b. The Impact Of Political Connections On Firms' Operating Performance And Financing Decisions. Journal of Financial Research, 35(3), 397-423.

Brewer, Thomas L, \& Rivoli, Pietra. 1990. Politics and Perceived Country Creditworthiness in International Banking. Journal of Money, Credit and Banking, 22(3), 357-369.

Busse, Matthias, \& Hefeker, Carsten. 2007. Political risk, institutions and foreign direct investment. European Journal of Political Economy, 23(2), 397-415.

Carrieri, Francesca, Chaieb, Ines, \& Errunza, Vihang. 2013. Do Implicit Barriers Matter for Globalization? Review of Financial Studies, 26(7), 1694-1739.

Carvalho, Daniel. 2014. The Real Effects of Government-Owned Banks: Evidence from an Emerging Market. Journal of Finance, 69(2), 577-609.

Chari, Anusha, \& Henry, Peter Blair. 2004. Risk Sharing and Asset Prices: Evidence from a Natural Experiment. Journal of Finance, 59(3), 1295-1324.

Chen, Nai-Fu, Roll, Richard, \& Ross, Stephen A. 1986. Economic Forces and the Stock Market. The Journal of Business, 59(3), 383-403. 
Clafessens, Stijn, Feijen, Erik, \& Laeven, Luc. 2008. Political connections and preferential access to finance: The role of campaign contributions. Journal of Financial Economics, 88(3), $554-580$.

Cooper, Michael J., Gulen, Huseyin, \& Ovtchinnikov, Alexei V. 2010. Corporate Political Contributions and Stock Returns. Journal of Finance, 65(2), 687-724.

Cosset, Jean-Claude, \& De la Rianderie, Bruno Doutriaux. 1985. Political Risk and Foreign Exchange Rates: an Efficient-Market Approach. Journal of International Business Studies, 16(3), 21-55.

Cuadra, Gabriel, \& SApriza, Horacio. 2008. Sovereign default, interest rates and political uncertainty in emerging markets. Journal of International Economics, 76(1), 78-88.

Darby, Julia, Li, Chol-Won, \& Muscatelli, V. Anton. 2004. Political uncertainty, public expenditure and growth. European Journal of Political Economy, 20(1), 153-179.

De Jong, Frank, \& de Roon, Frans A. 2005. Time-varying market integration and expected returns in emerging markets. Journal of Financial Economics, 78(3), 583-613.

Doidge, Craig, Karolyi, G. Andrew, \& Stulz, Rene M. 2004. Why are foreign firms listed in the U.S. worth more? Journal of Financial Economics, 71(2), 205-238.

Faccio, Mara. 2006. Politically Connected Firms. American Economic Review, 96(1), 369-386.

Fernandes, Nuno. 2009. Market liberalizations at the firm level: Spillovers from ADRs and implications for local markets. Journal of International Money and Finance, 28(2), 293-321.

Fisman, Raymond. 2001. Estimating the Value of Political Connections. American Economic Review, 91(4), 1095-1102.

Henisz, Witold J. 2000. The Institutional Environment for Multinational Investment. Journal of Law, Economics, and Organization, 16(2), 334-364.

Hillier, David, \& Loncan, Tiago. 2017. Stock market integration, cost of equity capital and corporate investment: Evidence from Brazil. European Financial Management, 1 -26.

Johnson, Robert R., Chittenden, William, \& Jensen, Gerald. 1999. Presidential Politics, Stocks, Bonds, Bills and Inflation. Journal of Portfolio Management, Fall, 27 -31.

Julio, Brandon, \& Yook, Youngsuk. 2012. Political Uncertainty and Corporate Investment Cycles. Journal of Finance, 67(1), 45-84. 
Kelly, Bryan, Pastor, Lubos, \& Veronesi, Pietro. 2016. The Price of Political Uncertainty: Theory and Evidence from the Option Market. Journal of Finance, 71(5), 2417-2480.

Lazzarini, Sergio, Musacchio, Aldo, Bandeira-de Mello, Rodrigo, \& Marcon, Rosilene. 2015. What do state-owned development banks do? Evidence from BNDES, 2002?09. World Development, 66, 237-253.

Leahy, Joe. 2015. BNDES: Lender of first resort for Brazil tycoons. Financial Times.

Lensink, Robert, Hermes, Niels, \& Murinde, Victor. 2000. Capital flight and political risk. Journal of International Money and Finance, 19(1), 73-92.

Liu, Laura Xiaolei, Shu, Haibing, \& Wei, K.C. John. 2017. The impacts of political uncertainty on asset prices: Evidence from the Bo scandal in China. Journal of Financial Economics, 125(2), 286-310.

MacKinlay, A. Craig. 1997. Event Studies in Economics and Finance. Journal of Economic Literature, 35(1), 13-39.

Papaionnnou, Elias. 2009. What drives international financial flows? Politics, institutions and other determinants. Journal of Development Economics, 88(2), 269-281.

Pastor, Lubos, \& Veronesi, Pietro. 2013. Political uncertainty and risk premia. Journal of Financial Economics, 110(3), 520-545.

Veronesi, Pietro. 1999. Stock Market Overreaction to Bad News in Good Times: A Rational Expectations Equilibrium Model. Review of Financial Studies, 12(5), 975-1007.

Yu, Frank, \& Yu, Xiaoyun. 2012. Corporate Lobbying and Fraud Detection. Journal of Financial and Quantitative Analysis, 46(06), 1865-1891. 
Table 4: Appendix - Industry statistics (averages)

\begin{tabular}{|c|c|c|c|c|c|c|c|c|c|c|}
\hline Industry & Firms & Ret $\mathrm{t}=0$ & Ret $5 \mathrm{~d}$ & CAR 5d & CAR 10d & Polcon Equity & ADR & Polcon board & Polcon debt & Polcon E+D \\
\hline Abrasive, asbestos and miscellaneous & 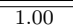 & 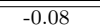 & 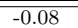 & 0.02 & 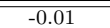 & 0.00 & 0.00 & 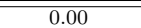 & 0.03 & 0.01 \\
\hline Agricultural chemicals & 1.00 & -0.15 & -0.15 & -0.05 & -0.17 & 0.00 & 0.00 & 0.00 & 0.00 & 0.00 \\
\hline Air transportation & 1.00 & -0.22 & -0.29 & -0.19 & -0.21 & 0.00 & 1.00 & 0.00 & 0.00 & 0.00 \\
\hline Aircraft and parts & 1.00 & 0.03 & 0.06 & 0.17 & 0.13 & 0.05 & 1.00 & 1.00 & 0.01 & 0.03 \\
\hline Animal services & 3.00 & -0.05 & -0.17 & -0.07 & -0.04 & 0.14 & 0.00 & 0.67 & 0.00 & 0.02 \\
\hline Arrangement of passenger & 1.00 & -0.10 & -0.08 & 0.02 & 0.04 & 0.00 & 0.00 & 0.00 & 0.00 & 0.00 \\
\hline Automotive rental & 1.00 & 0.00 & -0.01 & 0.10 & 0.05 & 0.00 & 0.00 & 0.00 & 0.00 & 0.00 \\
\hline Bakery products & 1.00 & -0.12 & -0.05 & 0.05 & 0.22 & 0.00 & 0.00 & 0.00 & 0.00 & 0.00 \\
\hline Beverages & 1.00 & -0.04 & -0.01 & 0.09 & 0.10 & 0.00 & 1.00 & 0.00 & 0.08 & 0.04 \\
\hline Bituminous coal and lignite & 1.00 & -0.14 & -0.12 & -0.02 & -0.02 & 0.00 & 0.00 & 0.00 & 0.00 & 0.00 \\
\hline Books & 2.00 & -0.16 & -0.21 & -0.11 & -0.17 & 0.00 & 0.00 & 0.00 & 0.22 & 0.14 \\
\hline Broadwoven fabric mills & 1.00 & -0.21 & -0.08 & 0.02 & 0.21 & 0.04 & 0.00 & 0.00 & 0.00 & 0.01 \\
\hline Colleges, universities & 3.00 & -0.13 & -0.01 & 0.09 & 0.11 & 0.00 & 0.00 & 0.00 & 0.00 & 0.00 \\
\hline Commercial printing & 1.00 & -0.11 & -0.24 & -0.14 & -0.11 & 0.00 & 0.00 & 0.00 & 0.00 & 0.00 \\
\hline Communications services & 4.00 & -0.06 & -0.05 & 0.05 & 0.02 & 0.01 & 0.75 & 0.00 & 0.00 & 0.00 \\
\hline Computer and office equipment & 1.00 & -0.15 & -0.22 & -0.12 & -0.04 & 0.00 & 0.00 & 0.00 & 0.40 & 0.27 \\
\hline Computer programming & 4.00 & -0.06 & -0.05 & 0.05 & 0.11 & 0.05 & 0.00 & 0.50 & 0.53 & 0.19 \\
\hline Construction, mining and equipment & 2.00 & -0.14 & -0.02 & 0.08 & 0.12 & 0.30 & 0.00 & 0.00 & 0.00 & 0.02 \\
\hline Converted paper & 1.00 & 0.08 & 0.13 & 0.23 & 0.28 & 0.05 & 0.00 & 1.00 & 0.54 & 0.42 \\
\hline Crude petroleum and natural gas & 3.00 & -0.11 & -0.09 & 0.01 & -0.02 & 0.06 & 0.33 & 0.00 & 0.00 & 0.02 \\
\hline Deep sea domestic transport & 1.00 & -0.10 & -0.13 & -0.02 & 0.03 & 0.00 & 0.00 & 0.00 & 0.02 & 0.02 \\
\hline Department stores & 6.00 & -0.13 & -0.12 & -0.02 & 0.02 & 0.00 & 0.00 & 0.00 & 0.17 & 0.11 \\
\hline Dolls, toys, games & 1.00 & -0.07 & -0.06 & 0.04 & 0.16 & 0.00 & 0.00 & 0.00 & 0.00 & 0.00 \\
\hline Drug stores & 2.00 & -0.10 & -0.10 & -0.00 & 0.06 & 0.00 & 0.00 & 0.00 & 0.28 & 0.13 \\
\hline Drugs & 1.00 & -0.06 & -0.04 & 0.07 & 0.05 & 0.00 & 0.00 & 0.00 & 0.00 & 0.00 \\
\hline Drugs wholesail & 1.00 & -0.14 & -0.17 & -0.07 & -0.15 & 0.00 & 0.00 & 0.00 & 0.00 & 0.00 \\
\hline Electric services & 15.00 & -0.10 & -0.04 & 0.06 & 0.05 & 0.07 & 0.29 & 0.29 & 0.03 & 0.05 \\
\hline Electronic components & 1.00 & -0.03 & -0.02 & 0.09 & 0.10 & 0.00 & 0.00 & 0.00 & 0.57 & 0.31 \\
\hline Fabricated structural metals & 1.00 & -0.09 & -0.12 & -0.02 & -0.11 & 0.00 & 0.00 & 0.00 & 0.00 & 0.00 \\
\hline Farm and garden machinery & 1.00 & -0.08 & -0.07 & 0.03 & 0.04 & 0.00 & 0.00 & 0.00 & 1.34 & 0.52 \\
\hline Ferroalloy ores & 1.00 & -0.04 & 0.04 & 0.14 & 0.08 & 0.00 & 0.00 & 0.00 & 0.48 & 0.09 \\
\hline Field crops & 2.00 & -0.06 & 0.02 & 0.12 & 0.12 & 0.00 & 0.00 & 0.00 & 0.05 & 0.02 \\
\hline Footwear, except rubber & 3.00 & -0.10 & -0.04 & 0.06 & 0.05 & 0.00 & 0.00 & 0.00 & 0.18 & 0.08 \\
\hline Fuel dealers & 1.00 & -0.05 & -0.00 & 0.10 & 0.10 & 0.00 & 1.00 & 0.00 & 0.00 & 0.00 \\
\hline Functions related to deposits & 1.00 & -0.05 & -0.03 & 0.07 & 0.09 & 0.00 & 0.00 & 0.00 & 0.03 & 0.02 \\
\hline Gas production and distribution & 2.00 & -0.07 & -0.00 & 0.10 & 0.06 & 0.00 & 0.00 & 0.00 & 0.10 & 0.07 \\
\hline Gasoline service station & 1.00 & -0.09 & -0.04 & 0.07 & 0.07 & 0.00 & 0.00 & 0.00 & 0.00 & 0.00 \\
\hline General industrial machinery & 2.00 & -0.08 & -0.06 & 0.04 & -0.04 & 0.00 & 0.00 & 0.00 & 0.84 & 0.42 \\
\hline Grocery stores & 1.00 & -0.11 & -0.07 & 0.03 & 0.05 & 0.00 & 1.00 & 0.00 & 0.00 & 0.00 \\
\hline Heavy construction & 1.00 & -0.08 & 0.03 & 0.13 & 0.36 & 0.00 & 0.00 & 0.00 & 0.00 & 0.00 \\
\hline Household audio and video & 1.00 & -0.11 & 0.03 & 0.13 & -0.01 & 0.00 & 0.00 & 0.00 & 0.00 & 0.00 \\
\hline Household furniture & 1.00 & -0.07 & -0.09 & 0.02 & -0.04 & 0.00 & 0.00 & 0.00 & 0.00 & 0.00 \\
\hline Industrial inorganic chemicals & 1.00 & -0.06 & -0.06 & 0.04 & 0.13 & 0.00 & 0.00 & 0.00 & 0.00 & 0.00 \\
\hline Insurance agents, brokers & 1.00 & -0.14 & -0.17 & -0.07 & 0.00 & 0.00 & 0.00 & 0.00 & 0.00 & 0.00 \\
\hline Investment offices & 2.00 & -0.17 & -0.14 & -0.04 & -0.09 & 0.07 & 0.00 & 0.50 & 0.00 & 0.02 \\
\hline Iron ores & 1.00 & 0.00 & 0.03 & 0.14 & 0.12 & 0.05 & 1.00 & 1.00 & 0.11 & 0.08 \\
\hline Knitting mills & 1.00 & -0.11 & 0.10 & 0.20 & 0.30 & 0.00 & 0.00 & 0.00 & 0.00 & 0.00 \\
\hline Land subdividers & 2.00 & -0.07 & -0.02 & 0.08 & 0.09 & 0.00 & 0.50 & 0.00 & 0.14 & 0.03 \\
\hline Life insurance & 1.00 & -0.11 & -0.02 & 0.08 & 0.04 & 0.00 & 0.00 & 0.00 & 0.00 & 0.00 \\
\hline Management and public relations & 1.00 & -0.20 & -0.29 & -0.18 & -0.15 & 0.00 & 0.00 & 0.00 & 0.00 & 0.00 \\
\hline Meat products & 1.00 & -0.02 & 0.02 & 0.12 & 0.12 & 0.00 & 1.00 & 0.00 & 0.06 & 0.05 \\
\hline Medical and dental labor & 2.00 & -0.06 & -0.03 & 0.08 & 0.09 & 0.00 & 0.00 & 0.00 & 0.00 & 0.00 \\
\hline Men's and boys' furnishings & 2.00 & -0.13 & -0.06 & 0.04 & 0.07 & 0.00 & 0.00 & 0.00 & 0.13 & 0.03 \\
\hline Metalworking machinery & 1.00 & -0.12 & 0.04 & 0.15 & 0.16 & 0.00 & 0.00 & 0.00 & 2.30 & 1.02 \\
\hline Miscellaneous amusement & 1.00 & -0.09 & -0.17 & -0.07 & 0.09 & 0.00 & 0.00 & 0.00 & 0.00 & 0.00 \\
\hline Miscellaneous business & 1.00 & -0.13 & -0.17 & -0.07 & -0.05 & 0.00 & 0.00 & 0.00 & 0.00 & 0.00 \\
\hline Miscellaneous chemical products & 1.00 & -0.07 & 0.16 & 0.26 & 0.32 & 0.00 & 0.00 & 0.00 & 0.08 & 0.04 \\
\hline Miscellaneous equipment & 1.00 & -0.16 & -0.11 & -0.01 & 0.07 & 0.00 & 0.00 & 0.00 & 0.00 & 0.00 \\
\hline Miscellaneous metal ores & 2.00 & -0.08 & -0.00 & 0.10 & 0.09 & 0.00 & 0.00 & 0.00 & 0.01 & 0.01 \\
\hline Miscellaneous services transportation & 1.00 & -0.15 & -0.09 & 0.01 & 0.04 & 0.00 & 0.00 & 0.00 & 0.00 & 0.00 \\
\hline Miscellaneous wood products & 1.00 & -0.14 & -0.07 & 0.04 & -0.04 & 0.00 & 0.00 & 0.00 & 0.13 & 0.07 \\
\hline Motor vehicles and equipments & 5.00 & -0.11 & -0.08 & 0.02 & 0.06 & 0.07 & 0.00 & 0.40 & 0.31 & 0.22 \\
\hline Offices and clinics & 1.00 & -0.13 & -0.12 & -0.02 & -0.04 & 0.00 & 0.00 & 0.00 & 0.00 & 0.00 \\
\hline Operative builders & 6.00 & -0.13 & -0.08 & 0.03 & -0.03 & 0.01 & 0.00 & 0.00 & 0.00 & 0.00 \\
\hline Ordnance and accessories & 1.00 & -0.05 & -0.05 & 0.05 & -0.01 & 0.00 & 0.00 & 0.00 & 0.00 & 0.00 \\
\hline Paper mills & 1.00 & 0.11 & 0.26 & 0.36 & 0.32 & 0.29 & 1.00 & 1.00 & 0.44 & 0.38 \\
\hline Pension, health & 1.00 & -0.10 & 0.14 & 0.24 & 0.29 & 0.00 & 0.00 & 0.00 & 0.00 & 0.00 \\
\hline Petroleum refining & 1.00 & -0.00 & -0.04 & 0.06 & 0.03 & 0.00 & 1.00 & 0.00 & 0.12 & 0.11 \\
\hline Professional equipment & 1.00 & 0.02 & 0.07 & 0.17 & 0.27 & 0.00 & 0.00 & 0.00 & 0.00 & 0.00 \\
\hline Railroads & 1.00 & -0.13 & -0.10 & 0.01 & 0.05 & 0.00 & 0.00 & 0.00 & 0.00 & 0.00 \\
\hline Real estate agents & 6.00 & -0.17 & -0.16 & -0.06 & -0.07 & 0.00 & 0.00 & 0.00 & 0.00 & 0.00 \\
\hline Real estate operators & 10.00 & -0.13 & -0.13 & -0.02 & -0.01 & 0.00 & 0.00 & 0.00 & 0.00 & 0.00 \\
\hline Refrigeration & 2.00 & -0.09 & 1.58 & 1.68 & 1.70 & 0.00 & 0.00 & 0.00 & 0.00 & 0.00 \\
\hline Retail stores & 1.00 & -0.10 & -0.27 & -0.17 & -0.22 & 0.00 & 0.00 & 0.00 & 0.00 & 0.00 \\
\hline Rubber and plastics footwear & 1.00 & -0.15 & -0.16 & -0.06 & 0.16 & 0.00 & 0.00 & 0.00 & 0.22 & 0.21 \\
\hline Security and commodity & 1.00 & -0.09 & -0.07 & 0.03 & 0.02 & 0.00 & 0.00 & 0.00 & 0.01 & 0.00 \\
\hline Services commodities & 1.00 & -0.04 & -0.14 & -0.04 & -0.13 & 0.00 & 0.00 & 0.00 & 0.00 & 0.00 \\
\hline Services incidental to water & 1.00 & -0.14 & -0.18 & -0.08 & -0.14 & 0.00 & 0.00 & 0.00 & 0.01 & 0.00 \\
\hline Soap, detergents and cleaning & 2.00 & -0.14 & 0.06 & 0.16 & 0.24 & 0.05 & 0.00 & 0.00 & 0.09 & 0.07 \\
\hline Steel works, blast furnaces & 4.00 & -0.16 & -0.05 & 0.06 & 0.06 & 0.00 & 0.50 & 0.25 & 0.04 & 0.02 \\
\hline Structural clay products & 2.00 & -0.08 & 0.01 & 0.11 & 0.19 & 0.02 & 0.00 & 0.00 & 0.04 & 0.03 \\
\hline Sugar and confectionery & 2.00 & -0.10 & -0.03 & 0.08 & 0.07 & 0.00 & 0.00 & 0.00 & 0.06 & 0.04 \\
\hline Terminals & 1.00 & -0.16 & -0.07 & 0.03 & 0.04 & 0.04 & 0.00 & 0.00 & 0.00 & 0.00 \\
\hline Trucking and courier services & 2.00 & -0.16 & -0.10 & 0.00 & 0.11 & 0.00 & 0.00 & 0.00 & 0.08 & 0.07 \\
\hline Watches, clocks & 1.00 & -0.17 & -0.15 & -0.05 & -0.01 & 0.00 & 0.00 & 0.00 & 0.00 & 0.00 \\
\hline Water supply & 2.00 & -0.11 & -0.10 & 0.00 & 0.05 & 0.02 & 0.00 & 0.00 & 0.28 & 0.15 \\
\hline Women's clothing stores & 1.00 & -0.18 & -0.18 & -0.08 & 0.01 & 0.00 & 0.00 & 0.00 & 0.00 & 0.00 \\
\hline
\end{tabular}

